Notaice

Vol. 2 No. 3, Oktober 2019
e-ISSN: 2655-9404

DOI: $10.20473 /$ ntr.v2i3.13399

Article history: Submitted 4 September 2019 ; Accepted 18 September 2019; Available online 1 October 2019.

\title{
Peralihan Hak Milik Sukuk Tabungan Melalui Pewarisan
}

\author{
Adam Setiawan, Riansyah Towidjojo dan Yazid Shidqi Faisal \\ setiawanqo@gmail.com \\ Universitas Airlangga
}

\begin{abstract}
One of the instrument in the shariah capital market is sukuk (sharia bond). Sukuk can be issued by companies or countries. At present there are 7 state sukuk instruments that have been issued by the giverment, two of which are intended for individual investors Indonesian citizens. State sukuk for individual investors are retail sukuk and sukuk savings. Both retail sukuk and sukuk savings are the same as state sharia securities issued to encourage the Indonesian people to invest and assist the country development because the procceds from the sale of these two sukuk will be used state insfrastructure development. However one of dissent is striking which this two sukuk is retail sukuk is tradable (transferable / traded) while the savings sukuk is non tredeble (non-tradable / non-transferable). So, how if thesukuk ownership pass away, is the sukuk ownership can change by legacy?. The nethode used in this is the statute approach and this research in the kegal context used a doctrinal legal research approach, but it dosen not rule out the possibility of legal interpretation method can do especially related to the problems to be research possession transfer the sukuk savings to inheriting can postponement legacy effect which is not justified in Islamic law or in the civil law.
\end{abstract}

Keywords: State Sukuk; Savings Sukuk; Sukuk Ownership.

\begin{abstract}
Abstrak
Salah satu instrumen dalam pasar modal syariah adalah sukuk(obligasi syariah).sukuk dapat dikeluarkan oleh perusahaan maupun negara. Saat ini ada 7 instrumen Sukuk Negara yg telah diterbitkan oleh Pemerintah, dua diantaranya ditujukan untuk investor individu Warga Negara Indonesia. Sukuk Negara untuk investor individu adalah sukuk ritel dan sukuk tabungan. Baik sukuk ritel maupun sukuk tabungan sama sama surat berharga syariah negara yang dikeluarkan untuk mengajak masyarakat Indonesia berinvestasi dan membantu pembangunan negara karena hasil penjualan dari kedua sukuk ini akan digunakan sebagai pembangunan infrastruktur negara. namun salah satu perbedaan yang paling mencolok dari kedua sukuk ini ialah sukuk ritel bersifat tradable (bisa dialihkan/diperdagangkan) sedangkan sukuk tabungan bersifatnon-tradble(tidak dapat diperdagangkan/tidak bisa dialihkan).lantas bagaimana jika pemilik sukuk meninggal dunia apakah kepemilikan sukuk ini bisa dialihkan melalui pewarisan. Metode yang digunakan dalam penelitian ini adalah statuteapproach dan Penelitian ini dalam konteks hukum menggunakan pendekatan penelitian hukumdoktrinal, namun tidak menutup kemungkinan untuk dapat dilakukan metode interpretasi hukumterutama terkait dengan masalah yang akan diteliti.perlihan hak milik sukuk tabungan melalui pewarisan ini bisa mengakibatkan penundaan pewarisan yang mana hal ini tidak dibenarkan dalam hukum Islam maupun dalam kitab undang-undang hukum perdata.
\end{abstract}

Kata Kunci: Sukuk Negara; Sukuk Tabungan; Kepemilikan Sukuk.

\section{Pendahuluan}

Keberadaaan pasar modal merupakan suatu realitas dan menjadi fenomena terkini ditengah tengah kehidupan umat manusia di abad modern inibahkan hampir semua negara negara diseluruh dunia ini menggunakan pasar modal 


\section{Adam Setiawan: Peralihan Hak Milik}

sebagai instrumen penting ekonomi. Begitu pula dengan tatanan mikro (firm-level performance), pasar modal telah menarik perhatian banyak kalangan pengusaha dan investor untuk terlibat didalamnya. Tentu dengan segala konsekuensi baik material maupun spritual yang banyak diantara mereka tidak menyadari.

Keberadaan pasar modal disuatu negara merupakan salah satu faktor signifikan dalam menentukan arah pembangunan ekonomi. Hal ini terbukti dari banyaknya industri dan perusahaan yang telah menggunakn institusi ini sebagai sarana untukmendapatkan sumber pembiayaan usaha Secara faktual, keberadaan pasar modal telah menjadi pusat saraf finansial (financial nerve centre) pada tatanan ekonomi dunia modern bahkan tanpa adanya lembaga pasar modal yang terorgarnisir dengan baik, tangguh dan berdaya saing global tatanan ekonomi dunia modern seakan tidak sempurna.

Pasar modal di Indonesia berperan besar terhadap perekonomian negara. Adanya pasar modal, investor dapat menginvestasikan dananya pada berbagai sekuritas yang tersedia dengan harapan dapat memperoleh imbalan yang sesuai. Pasar modal ini pun membantu keberlangsungan alternatif pendanaan berupa kegiatan beroperasi dan mengembangkan bisnis perusahaan. ${ }^{1}$

Pasar modal konvensional sendiri masih bersifat umum, karena belum menyentuh aspek apakah bentuk transaksi yang dijalankan atau efek yang diperdagangkan halal atau haram. Praktek kegiatan ekonomi konvensional,terutama melalui kegiatan dipasar modal banyak yang mengandung unsur spekulasi (gharar) dan menjadikan sistem riba sebagai landasan operasionalnya. untuk mengetahui hakikat halal atau haram maka kita harus mengembalikan ke determinasi syariah.

Kegiatan pasar modal yang dijalankan berdasarkan prinsip-prinsip syariah dapat disebut sebagai pasar modal syariah. Maksud dari prinsip syariah dipasar modal adalah prinsip prinsip hukum Islam dalam kegiatan dibidang pasar modal Berdasarkan Fatwa Dewan Syariah Nasional Majelis Ulama Indonesia (selanjutnya disingkat DSN-MUI) baik fatwa DSN-MUI yang ditetapkan dalam peraturan

${ }^{1}$ Kadek Agus Pradipta dan Ketut Alit Suardana, 'Pengaruh Kondisi Ekonomi, Kondisi Pasar Modal Dan Kinerja Keuangan Terhadap Return Saham’ (2015) 13 Akuntansi Universitas Udayana.[476]. 
Otoritas Jasa Keuangan(selanjutnya disingkat OJK) maupun fatwaDSN-MUI yang telah diterbitkan sebelum ditetapkannya peraturan ini (Peraturan Otoritas Jasa Keuangan Nomor 17/Pojk.04/2015 Tentang Penerbitan Dan Persyaratan Efek Syariah Berupa Saham Oleh Emiten Syariah Atau Perusahaan Publik Syariah), sepanjang fatwa dimaksud tidak bertentangan dengan peraturan ini dan atau peraturan OJK lain yang didasarkan pada fatwa MUI-DSN.

Instrumen pasar modal selain diwujudkan dalam bentuk saham, juga dapat diwujudan dalam bentuk obligasi. Pengertian obligasi dipasar modal syariah, tidak identik dengan surat pengakuan hutang sebagaiaman dkenal dalam pasar modal konvensional selama ini. Pengertiaan obligasi dalam pasar modal syariah memiliki makna yang lebih luas, yaitu meliputi beberapa akad yang dapat digunakan.

Alih alih memiliki makna sebagai surat hutang seperti pada pasar modal konvensional. Obligasi syariah dalam pasar modal syariah lebih condong memiliki arti sebagai surat berharga.layaknya pasar modal konvensional sukuk(obligasi syariah) dapat diterbitkan oleh perusahaan maupun pemerintah. Saat ini ada 7 instrumen Sukuk Negara yg telah diterbitkan oleh Pemerintah, dua diantaranya ditujukan untuk investor individu Warga Negara Indonesia. Sukuk Negara untuk investor individu adalah sukuk ritel dan sukuk tabungan.

Sukuk ritel maupun sukuk tabungan sama sama surat berharga syariah negara yang dikeluarkan untuk mengajak masyarakat Indonesia berinvestasi dan membantu pembangunan negara karena hasil penjualan dari kedua sukuk ini akan digunakan sebagaia pembangunan infrastruktur negara.namun salah satu perbedaan yang paling mencolok dari kedua sukuk ini ialah sukuk ritel bersifat tradable (bisa dialihkan/diperdagangkan) sedangkan sukuk tabungan bersifatnon-tradable(tidak dapat diperdagangkan).

Pewarisan merupakan pemberian dari orang yang meninggal dunia kepada orang yang masih hidup. Pemberian disini berupa aktiva maupun pasiva. Penerima warisan disebut waris jika Cuma seorang dan disebut ahli waris jika lebih dari seorang. Didalam hukum perdata barat (bw) ada 3 sikap yang dapat dipilih oleh penerima waris terkait pemberian waris: 
1. Menerima warisan dengan penuh (zuivere aanvaarding);

2. Menerima warisan secara beneficiaire (beneficiare aanvaarding);

3. Menolak warisan (verwerpen van erfenissen).

Dalam hukum Islam terdapat perbedaan pendapat mengenai sikap terhadap pemberian warisan. Menurut Guru Besar Hukum Perdata Islam Universitas Indonesia Prof. Tahir Azhary di dalam artikel Hukum Waris Islam Tak Mengenal Hak Ingkar. Dia menjelaskan, hak untuk menolak warisan hanya dikenal dalam hukum waris perdata Barat. Menurutnya, dalam hukum waris Islam, ahli waris tak boleh menolak warisan. ${ }^{2}$ Pemikiran Prof. Tahir Azhary tersebut sejalan dengan asas hukum kewarisan Islam yang dapat disalurkan dari Al-Quran dan al-Hadits yaitu asas ijbari. Seperti dijelaskan Prof. H. Mohammad Daud Ali, S.H. di dalam bukunya berjudul Hukum Islam. asas ijbari mengandung arti bahwa peralihan harta dari seorang yang meninggal dunia kepada ahli warisnya berlaku dengan sendirinya menurut ketetapan Allah tanpa digantungkan kepada kehedak pewaris atau ahli warisnya. ${ }^{3}$ Perbedaan pendapat datang dari Neng Djubaidah, pengajar Hukum Waris Islam di Fakultas Hukum Universitas Indonesia dan M. Ali Hasan yang berpendapat bahwa penolakan warisan oleh ahli waris dapat dilakukan jika disetujui oleh para ahli waris dan memang pengunduran diri tersebut atas dasar kerelaan dan niat yang baik. ${ }^{4}$

Seperti yang dijelaskan diatas Sukuk tabungan adalah sukuk yang tidak dapat diperdagangkan atau dialihkan hal ini menimbulkan pertanyaan. Lantas bagaimana jika pemilik sukuk meninggal dunia apakah tetap tidak bisa dialihkan melalui pewarisan kepemilikan sukuk tabungan tersebut, apakah hak milik sukuk tabungan dapat dialihkan melalui warisan dan apakah akibat hukum yang dapat terjadi dalam mekanisme pengalihan hak milik sukuk tabungan melalui pewarisan.

\footnotetext{
${ }^{2}$ Ali, 'Hukum Waris Islam Tak Mengenal Hak Ingkar' (Hukum Online, 2008) < https://www. hukumonline.com/berita/baca/hol18310/hukum-waris-islam-tak-mengenal-hak-ingkar\%3E $>$ accessed 6 September 2019.

${ }^{3}$ Mohammad Daud Ali, Hukum Islam (Rajagrafindo Persada 2012).[281-282].

${ }^{4}$ Letezia Tobing, 'Menolak Warisan Menurut Hukum Perdata Barat Dan Hukum Islam Diakses Pada Tanggal 06 September 2019' (Hukum Online, 2013).
} 
Tipe penelitian yang digunakan dalam penulisan ini adalah Penelitian Hukum oleh sebab itu Tidak perlu menggunakan istilah penelitian normatif karena istilah legal research atau bahasa Belanda rechtsonderzoek selalu normatif. ${ }^{5}$ Penelitian hukum merupakan suatu kegiatan know-how dalam ilmu hukum, bukan sekedar knowabout. ${ }^{6}$ Sebagai kegiatan know-how, penelitian hukum dilakukan untuk memecahkan isu hukum yang dihadapi. ${ }^{7}$ Disinilah dibutuhkan kemampuan untuk mengidentifikasi masalah hukum, melakukan penalaran hukum, menganalisis masalah yang dihadapi dan kemudian memberikan pemecahan atas masalah tersebut. ${ }^{8}$

Pendekatan yang digunakan dalam penelitian ini adalah pendekatan undangundang (statute approach) dan pendekatan konseptual (conceptual approach). Pendekatan undang-undang dilakukan dengan menelaah semua undang-undang dan regulasi yang berkaitan dengan isu hukum yang sedang ditangani. ${ }^{9}$ Pendekatan konseptual (conceptual approach) beranjak dari pandangan-pandangan dan doktrindoktrin yang berkembang dalam ilmu hukum. ${ }^{10}$

Adapun tujuan penelitian ini adalah untuk mengetahui apakah hak milik sukuk tabungan dapat dialihkan melalui pewarisan dan mengetahui upaya hukum yang dapat dilakukan dalam hal peralihan hak milik sukuk tabungan melalui pewarisan.

\section{Definisi Sukuk Tabungan}

Sukuk berasal dari bahasa Arab yaitu sak (tunggal) dan sukuk (jamak) yang memiliki arti mirip dengan sertifikat atau note. Definisi sukuk / sertifikat ialah sertifikat bernilai sama dengan bagian atau seluruhnya dari kepemilikan harta berwujud untuk mendapatkan hasil dan jasa didalam kepemilikan aset dan proyek tertentu atau aktivitas investasi khusus, sertifikat ini berlaku setelah menerima nilai

\footnotetext{
5 Peter Mahmud Marzuki, Penelitian Hukum (Kencana 2014).[55].

6 ibid.[60].

ibid.[60].

8 ibid.[60].

9 ibid.[133].

10 ibid.[135].
} 
sukuk, saat jatuh tempo menerima dana sepenuhnya sesuai dengan sukuk tersebut. ${ }^{11}$ Sukuk ini bukan merupakan istilah yang baru dalam sejarah Islam. Istilah tersebut sudah dikenal sejak abad pertengahan, dimana umat Islam menggunakannya dalam konteks perdagangan international.Sukuk dipergunakan oleh para pedagang pada masa itu sebagai dokumen yang menunjukkan kewajiban finansial yang timbul dariusaha perdagangan dan aktivitas komersial lainnya. ${ }^{12}$ Menurut sharia standard no. 17 tentang investment mendefinisikan sukuk sebagai berikut:

"investment sukuk are certificates of equal value representing undivided shares in ownership of tangible assets, usufrucht and services or (in the ownership of) the assets or particular project or speccial investment activity, however, this is true after receipt of the value of the sukuk, the closing of subcription and the employment of funds received for the purposefor which the sukuk were issued".

Menurut Peraturan Otoritas Jasa Keuangan Nomor 18/Pojk.04/2015 Tentang Penerbitan Dan Persyaratan Sukuk. Sukuk adalah Efek Syariah berupa sertifikat atau bukti kepemilikan yang bernilai sama dan mewakili bagian yang tidak terpisahkan atau tidak terbagi (syuyu'/undivided share), atas aset yang mendasarinya.

Menurut hitungan rasional, instrumen sukuk lebih menguntungkan daripada obligasi konvensional, seperti nilai pemgembalian yang lebih menjanjikan, sistem kepemilikannya, dan keamanan investasi yang ditanggung pemerintah. Dari beberapa pengalaman yang ada, masih tersimpan beberapa penyebab yang sangat mungkin menghambat perkembangan sukuk di Indonesia. ${ }^{13}$

Sukuk Negara untuk investor individu yang dikeluarkan pemerintah ada 2 jenisyaituSukuk Ritel dan Sukuk Tabungan. Sukuk Ritel adalah Sukuk Negara yang ditujukan untuk investor individu Warga Negara Indonesia (WNI) dengan jangka waktu 3 tahun, Imbalan tetap dibayar per bulan, dapat diperdagangkan di pasar sekunder (Tradable), minimum pembelian Rp.5.000.000 (lima juta Rupiah) maksimum Rp.5.000.000.000 (lima miliar Rupiah). Sukuk Ritel diterbitkan sejak tahun 2009.

\footnotetext{
${ }^{11}$ Erma Sri Hastuti, 'Sukuk Tabungan: Investasi Syariah Pendorong Pembangunan Ekonomi Inklusif' (2017) 7 Jurisprudence.[116].

${ }^{12}$ Burhanuddin, Pasar Modal Syariah (UII Press 2009).[57].

${ }^{13}$ Candra Fajri Ananda, 'Pembiayaan Syariah Dan Percepatan Infrastruktur' (Sindo News, 2016).
} 
Sukuk tabungan adalah adalah produk investasi syariah yang ditawarkan oleh Pemerintah kepada individu Warga Negara Indonesia yang ditawarkan dalam mata uang Rupiah melalui Agen Penjual yang diterbitkan tanpa warkat dengan jangka waktu masa tenor 2 tahun.Struktur yang digunakan adalah Sukuk akad Wakalah .Imbalan kupon pada seri ST-001 bersifat tetap namun sejak seri ST-002 hingga seri terbaru ST-004 bersifat mengambang dengan tingkat imbalan minimal (floating with floor) mengacu pada BI 7-Day (Reverse) Repo Rate + spread (xxx bps) yang disesuaikan setiap 3 bulan ,dibayar per bulan,tidak dapat diperdagangkan di pasar sekunder (Untradable) namun memillik faslitas early redemption, minimum pembelian Rp.1.000.000(satu juta rupiah) maksimum Rp3.000.000.000(tiga miliar Rupiah). Sukuk Tabungan diterbitkan sejak tahun 2016.

Dasar hukum penerbitan sukuk tabungan adalah UU Nomor 19 Tahun 2008 tentang surat berharga syariah negara (selanjutnya disingkat SBSN), dan Peraturan Menteri Keuangan (selanjutnya disingkat PMK) Nomor 19 Tahun 2015 tentang penerbitan dan penjualan Sukuk Tabungan, sebagaimana telah diubah dengan PMK Nomor 10 Tahun 2016.Sukuk tabungan menggunakan akad Wakalah (investment agency sukuk). Mengacu pada Fatwa Dewan Syariah Nasional - MUI Nomor 95 Tahun 2014 tentang SBSN Wakalah.

\section{Keuntungan sukuk tabungan;}

1. Pembayaran Imbalan/Kupon dan Nilai Nominal dijamin oleh Negara berdasarkanUndang-Undang SBSN dan Undang-Undang APBN setiap tahunnya, sehingga Sukuk Tabungan seri tidak mempunyai risiko gagal bayar;

2. Pada saat diterbitkan, Imbalan/Kupon Sukuk tabungan ditawarkan lebih tinggi dibandingkan rata-ratatingkat bunga deposito bank Badan Usaha Milik Negara.

3. Imbalan/Kupon mengambang dengan jaminan kupon minimal (floor) sampai denganTanggal Jatuh Tempo;

4. Imbalan/Kupon Sukuk tabungan dibayar setiap bulan;

5. Terdapat fasilitas Early Redemption tanpa dikenakan Redemption Cost;

6. Kemudahan akses untuk melakukan Pemesanan Pembelian dan pengajuan Early Redemption melalui Sistem Elektronik;

7. Memberikan kesempatan kepada masyarakat untuk turut serta mendukung pembiayaanpembangunan nasional;

8. Memberikan akses kepada investor untuk berpartisipasi dalam aktivitas pasar keuangandengan cara dan metode yang tidak bertentangan dengan prinsipprinsip syariah. 


\section{Risiko Sukuk Tabungan}

Ada 3 (tiga) jenis risiko potensial yang perlu dipertimbangkan oleh investor dalam berinvestasi pada Sukuk tabungan sebagaimana halnya instrumen investasi lainnya yang diterbitkanoleh Pemerintah. Tiga jenis risiko tersebut adalah:

1. Risiko gagal bayar (default risk) adalah risiko apabila investor tidak dapat memperolehpembayaran dana yang dijanjikan oleh penerbit pada saat produk investasi jatuh tempobaik Imbalan/Kupon dan Nilai Nominal.Sebagai instrumen pasar modal, termasuk instrumen yang bebas risiko (risk freeinstrument) karena pembayaran Imbalan/Kupon dan Nilai Nominal Sukuk tabugan dijamin olehPemerintah berdasarkan Undang-Undang SBSN dan Undang-Undang APBN.

2. Risiko likuiditas (liquidity risk), adalah kesulitan dalam menjual Sukuk tabungan sebelum jatuhtempo apabila investor memerlukan dana tunai.Sukuk tabungan memiliki risiko likuiditas karena tidak dapat diperdagangkan dan dialihkan.Namun Sukuk tabungan dapat dicairkan sebelum jatuh tempo dengan memanfaatkan fasilitasEarly Redemption.

3. Risiko Tingkat Imbalan/Kuponadalah risiko berkurangnya Imbalan/Kupon yang diterimainvestor karena adanya perubahan Tingkat Imbalan Acuan. Sukuk tabungan tidak memiliki risiko tingkat Imbalan/Kupon karena tingkat Imbalan/ Kupon Sukuk tabungan yang ditetapkan pada saat penerbitan merupakan jaminan tingkat Imbalan/Kuponminimal (floor) yang akan diterima investor sampai dengan jatuh tempo.

\section{Peralihan Hak Milik Sukuk Tabungan Melalui Warisan}

Dalam Pasal 584 BW dikatakan:

"Hak milik atas suatu benda tidak dapat diperoleh dengan cara lain melainkan dengan pemilikan, karena perlekatan, karena daluwarsa, karena pewarisan, baik menurut undang-undang maupun menurut surat wasiat dan karena penunjukkan atau penyerahan berdasar atas suatu peristiwa perdata untuk memindahkan hak milik, dilakukan oleh seorang yang berhak berbuat bebas terhadap benda itu".

Pasal diatas mengatur secara umum cara memperoleh hak milik atas suatu benda yang salah satunya peralihan hak milik dapat dilakukan melalui pewarisan. 
benda sendiri dibagi menjadi dua benda bergerak dan benda tidak bergerak. perolehan benda bergerak pada umunya melalui penyerahan benda tersebut dan perolehan milik benda tidak bergerak biasanya melalui penanda tangan suatu perjanjian/kesepakatan. Dalam hal ini penulis beranggapan bahwa sukuk tabungan adalah benda bergerak.

Dalam hukum waris Islam baik aktiva maupun pasiva ikut beralih dalam pewarisan.Berkaitan dengan hokum waris Islam, maka jenis harta setidak-tidaknya terdiri dari beberapa jenis yaitu: ${ }^{14}$

1. Harta Peninggalan

Harta peninggalan diatur dalam pasal 171 huruf d Kompilasi hukum Islam(selanjutnya disingkat KHI).Harta peninggalan merupakan semua harta pewaris dalam bentuk bruto,yang terdiri dari semua harta benda miliknya ditambah hak-hakmya(sebagaimana dijabarkan dalam pasal $175 \mathrm{KHI}$ ).

\section{Harta Waris}

Harta waris diatur dalam pasal 171 huruf e KHI harta waris merupakan harta pewaris yang telah dalam mondisi neto, yang terdiri dari harta bawaan ditambah harta bersama serta dikurangi keperluan pewaris; misalnya keperluan pewaris selama sakit, biaya pengurusan jenasah(tahjiz), pembayaran utang,pemberian untk kerabat dan sebagainya.

Dalam memorandum informasi sukuk tabungan dikatakan bahwa salah satu resiko sukuk tabungan adalah resiko likuiditas.resiko likuiditas adalah kesulitan dalam menjual sebelum jatuh tempo ketika investor memerlukan dana tunai. Sukuk tabungan memiliki risiko likuiditas karena tidak dapat diperdagangkan dan dialihkan. Namun sukuk tabungan dapat dicairkan sebelum jatuh tempo dengan memanfaatkan fasilitas Early redemption.

Pada pasal 25 Peraturan Menteri Keuangan Nomor 19/Pmk.08/2015 Tentang Penerbitan Dan Penjualan Surat Berharga Syariah Negara Tabunganpun menyatakan bahwa kepemilikan atas sukuk tabungan tidak dapat dialihkan kepada pihak lain.

${ }^{14}$ Sri Hajati, Hukum Waris Adat, Islam, \& Burgerlijk Wetboek (Airlangga University Press 2018).[207-208]. 
Namun pada pasal 26 ayat 2 Peraturan Menteri ini menyatakan bahwa Dalam hal pemegang Sukuk Tabungan meninggal dunia, ahli waris pemegang Sukuk Tabungan dapat melakukan pencairan Sukuk Tabungan sebelum tanggal jatuh tempo dalam hal ini menggunakan early redemption. Seperti yang sudah dibahas diatas yang dapat melakukan early redemption hanyala pemegang sukuk yang bertransaksi minimal 2 juta rupiah. Jumlah yang dapat dicairkan pun hanya $50 \%$ dari jumlah sukuk.

Sukuk tabungan ini tidak bisa dipindahtangankan. Sebab Sukuk ini termasuk dalam kategori untradeable. Imbal hasil dari sukuk tabungan bisa diwariskan tapi harus sesuai jadwal early reedem, yakni satu tahun atau menunggu usai masa tenor 2 tahun. Jadi, tidak bisa langsung dialihkan di tengah jalan. Ada waktunya.

Menuggu jadwal early redeem atau menunggu masa tenor 2 tahun ini untuk pengalihan sukuk tabungan ini dapat mengakibatkan penundaan warisan. Dalam hukumwaris Islampenundaan warisan boleh dilakukan asalkan semua pihak yang mempunyai hak atas warisan tersebut sepakat untuk menunda pembagian harta waris tersebut dengan penuh kerelaan/keikhlasan. Yang perlu dipahami sejak awal adalah bahwa harta warisan merupakan hak bagi setiap orang yang secara sah menjadi ahli waris dari orang yang meninggal dunia. Karena ini menjadi hak maka pemilik hak dapat memintanya kapan pun ia mau baik ketika ia membutuhkan ataupun tidak membutuhkan. Dan karena harta warisan merupakan hak maka menunda pembagian warisan tanpa ada kerelaan dari semua ahli waris yang ada adalah sebuah tindakan yang tidak dibenarkan.

Tidak dibenarkan karena penundaan ini menjadikan hak orang lain menjadi terganggu. terdapat beberapa kewajiban yang mesti dilakukan sebelum membagi harta warisan. Pertama, membayar biaya pengurusan jenazah, kedua membayar utang. Utang kepada Allah dan utang kepada manusia. Utang kepada Allah seperti zakat. Sedangkan utang kepada manusia bisa orang atau negara seperti pajak. Ketiga yang harus dilakukan ahli waris adalah adalah menunaikan wasiat. Sebagian ulama menganggap menunda pembagian harta warisan dapat menimbulkan keburukan. Karena tidak semua ahli waris secara ekonomi mampu. Menunda pembagian warisan akan menzalimi keluarga lainnya. 


\section{Akibat Hukum Penundaan Pewarisan Pada Mekanisme Peralihan hak milik Sukuk Tabungan}

Berdasarkan kitab undang-undang hukum perdata (selanjutnya disingkat KUHPER) ahli waris mempunyai hak-hak sebagai berikut:

1. hak saisine (pasal 833 ayat (1) KUHPER) $)^{15}$

Ahli waris karena hukum memiliki barang-barang, hak-hak dan segala piutang dari orang yang meninggal dunia. Hal ini disebut, mereka (ahli waris) mempumyai saisine. Kata saisine diambil dari pepatah perancis :"le mort saisist le vif",artinya yang mati dianggap menggantikan yang hidup

2. Hak hereditatis petition (pasal 834-835 KUHPER)

Yaitu setiap ahli waris berhak melakukan penuntutan hukum untuk memperjuangkan hak warisnya,terhadap segala mereka yang baik atas dasar hak yang sama, baik tanpa dasar sesuatu hak pun menguasai seluruh atau sebagian harta peninggalan, seperti pun terhadap mereka yang secara melanggar hukum telah menghentikan penguasaannya.gugatan hereditatis petition ini berdasarkan pasal 835 bw gugur karena kadaluwarsa dengan tenggang waktu selama 30 tahun

3. hak untuk menuntut pembagian warisan/ hak menuntut pemisahan harta warisan (boedelafscheiding)(pasal 1066 KUHPER)

Ciri khas dalam hukum waris KUHPER antara lain adanya hak mutlak dari para ahli waris masing-masing untuk sewaktu-waktu menuntut pembagian dari harta warisan.

4. hak untuk menolak warisan (pasal 1045 jo.1051 KUHPER)

Tiada seorang pun diwajibkan untuk menerima suatu warisan yang jatuh kepadanya, sehingga menolak warisan merupakan suatu hak yang dapat digunakan atau tidak digunakan dalam hal warisan jatuh meluang.

5. hak untuk berfikir (pasal 1023 KUHPER)

Hak untuk berfikir hanya 4 bulan sejak warisan jatuh meluang dan harus segera menentukan sikap untuk menerima dengan murni, menolak atau menerima dengan catatan.

15 ibid.[246-247]. 
Dari kelima hak diatas,penulis merasa hak hereditatis petition bisa dijadikan dasar untuk menuntut mengenai pengalihan hak milik sukuk tabungan melalui warisan yang harus segera diwariskan ketika para ahli waris sudah membuat kesepakatan untuk membagi warisan. Dimana hak waris seseorang dikuasai oleh pihak lain dan belum bisa dialihkan dapat diajukan tuntutan. Tuntutan tersebut dapat diajukan kepada sesama ahli waris yang menguasai seluruh atau sebagian harta warisan, kepada pihak ketiga yang menguasai harta peninggalan, dan/atau kepada mereka yang meskipun tidak mempunyai hak atas suatu warisan namun telah memindah tangankan harta warisan tersebut. ${ }^{16}$ pasal 834 KUHPerdata yang berbunyi :

"Tiap-tiap waris berhak mengajukan gugatan guna memperjuangkan hak warisnya, terhadap segala mereka, yang baik atas dasar hak yang sama, baik tanpa dasar sesuatu hak pun menguasai seluruh atau sebagian harta peninggalan, seperti pun terhadap mereka, yang secara licik telah menghentikan penguasaannya.Ia boleh memajukan gugatan itu untuk seluruh warisan, jika ia adalah waris satu-satunya, atau hanya untuk sebagian jika ada berapa waris lainnya."

Sukuk tabungan termaksud salah satu unsur dari ekonomi syariah. Dalam konteks hukum di Indonesia, penyelesaian sengketa ekonomi syariah dapat dilakukan melalui dua model, yaitu penyelesaian secara litigasi dan non litigasi. ${ }^{17}$ Penyelesaian secara litigasi merupakan wilayah kompetensi pengadilan agama.Penyelesaian sengketa melalui pengadilan (litigasi) telah menjadi kewenangan Pengadilan Agama berdasarkan Pasal 49 Undang-Undang Nomor 3 Tahun 2006 tentang Peradilan Agama. Penetapan Pengadilan Agama sebagai penyelesaian sengketa ekonomi syariah berdasarkan Pasal 49 Undang-Undang Peradilan Agama memberikan perluasan kewenangan kepada Pengadilan Agama. Dengan perluasan kewenangan Pengadilan Agama sebagai pemutus sengketa ekonomi syariah membawa konsekuensi hukum bahwa pengadilan negeri tidak lagi berwenang untuk menyelesaikan sengketa ekonomi syariah. Pasal 49 Undang-Undang Nomor 3 Tahun 2006 menyatakan

${ }^{16}$ Oemar moechtar, 'Kedudukan Negara Sebagai Pengelola Warisan Atas Harta Peninggalan Tak Terurus Menurut Sistem Waris Burgerlijk Wetboek’ (2017) 32 Yuridika.

17 Kelik pramudya, 'Strategi Pengembangan Ekonomi Syariah Melalui Penguatan Fungsi Pengadilan Agama Dalam Penyelesaian Sengketa’ (2018) 7 Rechtsvinding.[39]. 
bahwa "Pengadilan Agama bertugas dan berwenang memeriksa, memutus, dan menyelesaikan perkara-perkara di tingkat pertama antara orang-orang yang beragama Islam di bidang perkawinan, waris, wasiat, hibah, wakaf, zakat, infaq, shadaqah; dan ekonomi syariah". Didalam Penjelasan Pasal 49 diuraikan lebih lanjut bahwa yang dimaksud "antara orang yang beragama Islam" adalah termasuk orang atau badan hukum yang dengan sendirinya menundukkan diri dengan sukarela kepada hukum Islam mengenai hal-hal yang menjadi kewenangan Peradilan Agama.

Dalam kaitannya menyelesaikan sengketa ekonomi syariah, Pengadilan Agama berwenang pula mengadili tentang tuntutan ganti rugi (ta'wid, daman) baik yang disebabkan oleh adanya wanprestasi ataupun karena adanya perbuatan melawan hukum. Acuan untuk mengadili ganti rugi ini adalah Undang-Undang Nomor 10 Tahun 1998 Pasal 19 jo Peraturan Bank Indonesia Nomor 7/46/PBI/2005 dan Fatwa DSN Nomor 43/DSN-MUI/VIII/2004. ${ }^{18}$ Untuk pilihan penyelesaian sengketa secara non-litigasi dapat dibagi dua, yaitu melalui arbitrase dan alternatif penyelesaian sengketa.

\section{Kesimpulan}

Pengalihan hak milik sukuk tabungan melalui pewarisan tidak bisa langsung dialihkan ketika pewaris meninggal dunia karena harus menuggu masa tenor 2 tahun atau masa early redemption setahun. Mekanisme pengalihan sukuk tabungan ini dapat menyebabkan penundaan pembagian warisan dan bisa jadi menimbulkan sengketa antara para ahli waris dengan Negara karena sukuk tabungan merupakan surat berharga syariah Negara.

\section{Daftar Bacaan}

\section{Buku}

Ali MD, Hukum Islam (Rajagrafindo Persada 2012).

Ananda CF, 'Pembiayaan Syariah Dan Percepatan Infrastruktur' (Sindo News, 2016).

\footnotetext{
${ }^{18}$ Erie Hariyanto, 'Penyelesaian Sengketa Ekonomi Syariah Di Indonesia' (2014) 1 Iqtashidia.[45].
} 
Burhanuddin, Pasar Modal Syariah (UII Press 2009).

Marzuki PM, Penelitian Hukum (Kencana 2014).

Sri Hajati, Hukum Waris Adat, Islam, \& Burgerlijk Wetboek (Airlangga University Press 2018).

\section{Jurnal}

Erma Sri Hastuti, 'Sukuk Tabungan: Investasi Syariah Pendorong Pembangunan Ekonomi Inklusif' (2017) 7 Jurisprudence.

Hariyanto E, 'Penyelesaian Sengketa Ekonomi Syariah Di Indonesia' (2014) 1 Iqtashidia.

Kadek Agus Pradipta dan Ketut Alit Suardana, 'Pengaruh Kondisi Ekonomi, Kondisi Pasar Modal Dan Kinerja Keuangan Terhadap Return Saham’ (2015) 13 Akuntansi Universitas Udayana.

Kelik pramudya, 'Strategi Pengembangan Ekonomi Syariah Melalui Penguatan Fungsi Pengadilan Agama Dalam Penyelesaian Sengketa' (2018) 7 Rechtsvinding.

Oemar moechtar, 'Kedudukan Negara Sebagai Pengelola Warisan Atas Harta Peninggalan Tak Terurus Menurut Sistem Waris Burgerlijk Wetboek' (2017) 32 Yuridika.

\section{Laman}

Ali, 'Hukum Waris Islam Tak Mengenal Hak Ingkar' (Hukum Online, 2008) $<$ https://www.hukumonline.com/berita/baca/hol18310/hukum-waris-islamtak-mengenal-hak-ingkar\%3E $>$ accessed 6 September 2019.

Letezia Tobing, 'Menolak Warisan Menurut Hukum Perdata Barat Dan Hukum Islam Diakses Pada Tanggal 06 September 2019' (Hukum Online, 2013).

HOW TO CITE: Adam Setiawan, Riansyah Towidjojo dan Yazid Shidqi Faisal, 'Peralihan Hak Milik Sukuk Tabungan Melalui Pewarisan' (2019) Vol. 2 No. 3 Notaire. 